\title{
Physcomitrium eurystomum Sendtn., a new moss species in the bryophyte flora of Montenegro
}

\author{
Danijela Stešević*, Branko Anđić, Milica Stanišić-Vujačić \\ Faculty of Natural Sciences and Mathematics, University of Montenegro, Džordža Vašingtona bb, 81000 Podgorica, \\ Montenegro
}

\begin{abstract}
In a vegetation survey conducted in the northeast part of Montenegro, Physcomitrium eurystomum Sendtn. was collected. This is a new moss species for the bryophyte flora of Montenegro. The species has a wide temperate-tropical distribution, but its populations are rather scattered. In most European countries, the species is included on the relevant national Red Lists and most recently, it was added to the European Red List of Mosses, Liverworts and Hornworts. In order to expand our knowledge of its distribution in Montenegro, and to assess its IUCN threat status, further investigations are needed.
\end{abstract}

Keywords: Biodiversity, conservation, Funariaceae.

\section{Introduction}

Bryological research in Montenegro has been intensified over the last two decades, and this has resulted in a significant number of new publications and records (Anđić et al. 2018). Nevertheless, because some regions still remain completely unexplored, our knowledge of the diversity of the bryophyte flora of Montenegro cannot be considered complete and new discoveries can be expected.

During vegetation research in the gorge of Bukovička Rijeka (in the northeast part of Montenegro), one new moss species belonging to the bryophyte flora of Montenegro was collected - Physcomitrium eurystomum Sendtn. Although, this temperate-tropical example of bryophyte flora (Dierßen 2001) is distributed across Europe, tropical Africa, and southern, southeastern and southwestern parts of Asia, its populations are rather scattered (Porley 2013, Hodgetts 2015). The European scope of the range includes: to the north Denmark, to the west Great Britain, in the south France and Italy, in central areas Austria, Belgium, the Czech Republic, Germany, Hungary, the Netherlands, Poland, Slovakia and Switzerland, in the southeast Bulgaria, Romania, Slovenia, Serbia and Turkey, and in the east Belarus, the Crimea, Latvia, northwest Russia and Ukraine (Papp et al. 2013, ECCB 2016). In the majority of these countries it has a defined status category, and it was recently included in the European Red List of Mosses, Liverworts and Hornworts (Hodgetts et al. 2019).
In this paper, we present the details of the first record of $P$. eurystomum in Montenegro; however, in order to extend our knowledge of its distribution in the whole country, and to define its conservation status, further investigations are needed.

\section{Material and methods}

\section{The study area}

Bukovička Rijeka, located in the northeast part of Montenegro, is a left tributary of the Ibar River; it is formed by two arms that originate at 1500 and $1600 \mathrm{~m}$ a.s.l. After 20 $\mathrm{km}$ and a drop of ca. 600-700 m, it flows into the Ibar River at $865 \mathrm{~m}$ a.s.l. Although the river is water poor, it has strong erosive energy; thus, it has carved a narrow, $200 \mathrm{~m}$ deep and $5 \mathrm{~km}$ long gorge in the middle and lower part of its flow. This gorge is very narrow; in some areas, the two sides of the gorge are just $5 \mathrm{~m}$ from each other. The geological substrate consists of lower and middle Triassic limestone. The climate fits into the cold alpine type with long and snowy winters, and short and fresh summers. The gorge is characterized by an inversion of both temperature and vegetation, which means, for example, that the mesophilous beech forests (Fagion moesiacae Blečić et Lakušić 1970) are developed in lower positions along the gorge, and thermophilous oak and hornbeam forests (Ostryion carpinifoliae Lakušić 1975) in the upper ones (Markišić and Martinović 1998).

\footnotetext{
*Corresponding author e-mail: danijela.stesevic@ucg.ac.me
} 


\section{Sampling}

Specimens of Physcomitrium eurystomum were collected in June 2018 during a vegetation survey of Bukovička Rije$\mathrm{ka}$, from the muddy soils alongside the stream. The species was identified according to Smith (2004), while the nomenclature follows Ros et al. (2013). Specimens were deposited in the Herbarium Collection at the University of Montenegro (TGU), Voucher number 1419038. During the field trip, notes on the relevant habitats, substrates and associated bryophytes were taken.

\section{Results and discussion}

\section{Physcomitrium eurystomum Sendtn.}

Specimen examined: Montenegro; Gorge of Bukovička Rijeka, 42 $55^{\prime} 22^{\prime \prime} \mathrm{N}, 20^{\circ} 15^{\prime} 31^{\prime \prime} \mathrm{E}, 970 \mathrm{~m}$ a.s.l.; Date: June 23, 2018; Leg. et Det.: D. Stešević, B. Anđić, M. Stanišić-Vujačić; Taxonomic confirmation: Beata Papp; Herbarium number (TGU): 1419038.

In the muddy soil deposits in the gorge at a distance of ca. $4 \mathrm{~m}$ from the water body, two turfs of Physcomitrium eurystomum were found (Fig. 1), of an approximate size of 5 $\mathrm{cm}^{2}$ each. On both patches, fruiting gametophytes were noticed. The P. eurystomum was accompanied by Marchantia polymorpha L., Bryum pseudotriquetrum (Hedw.) P. Gaertn., Weissia controversa Hedw. and Riccia sp., all growing in the shadow of Petasites hybridus (L.) G. Gaertn., B. Mey. et Scherb. Physcomitrium eurystomum is considered to be one of the representative species for Habitat Type C $3.5 \mathrm{~b}$ - Periodically exposed shore with stable, mesotrophic sediments with pioneer or ephemeral vegetation (Deil 2005), which is quoted in the European Red List of Habitats. At this rather remote site in the gorge of Bukovička Rijeka, human impact is completely absent; thus, the only possible threat to the species might be a change in the watercourse or the configuration of the riverbank.

Up to now, the Bryophyte flora of Montenegro has included only one species of the genus Physcomitrium - the cosmopolitan species $P$. pyriforme, which, according to Sabovljević et al. (2004), is classified as LR (low risk) on the Bryophyte Red List of Serbia and Montenegro.

So far the species has been reported in 22 European countries (Papp et al. 2013, ECCB 2016), while in 15 it has a defined status category: Endangered in Great Britain (Hodgetts 2011) and Hungary (Papp et al. 2010); Highly Endangered in Austria (ECCB 2016); Vulnerable in Germany (ECCB 2016), the Czech Republic (Kučera and Váňa 2003), Slovakia (Šoltés et al. 2002), Switzerland (BAFU 2011), and Estonia (Ingerpuu et al. 2018); Threatened in Belarus (Maslovsky 2005), Belgium (ECCB 2016), Bulgaria, Romania and Turkey (Sabovljević et al. 2001); Susceptible in the Netherlands (ECCB 2016) and Data Deficient in Slovenia (Martinčić 2016). In the Balkan peninsula, the species is reported in Serbia (Papp et al. 2013), Bulgaria, and Slovenia (Sabovljević et al. 2008), but due to the presence of similar habitat types in other parts of the peninsula, new records are expected. More recently, the P. eurystomum was included on the European Red List of Mosses, Liverworts and Hornworts (Hodgetts et al. 2019), within the following IUCN Red List Categories: Europe VU B2b(ii,iii)c(iii,iv) and EU 28 (28 European Union countries) EN B2b(ii,iii)c(iii,iv). Considering its status in Montenegro, based on what is currently limited knowledge, it is not possible to assess its IUCN conservation status. As such, further investigations are needed and recommended. Taking into account its international status category, we consider the species to be a good potential candidate for the new and supplemented list of protected plants in Montenegro.

\section{Acknowledgements}

This study was financially supported by the Montenegrin Ministry of Science within the bilateral project with Austria "Vegetation of the rock crevices with special focus to the Moltkeetalia petraeae order". We would like to thank to the anonymous reviewers for their careful reading of our manuscript and many valuable suggestions and comments.
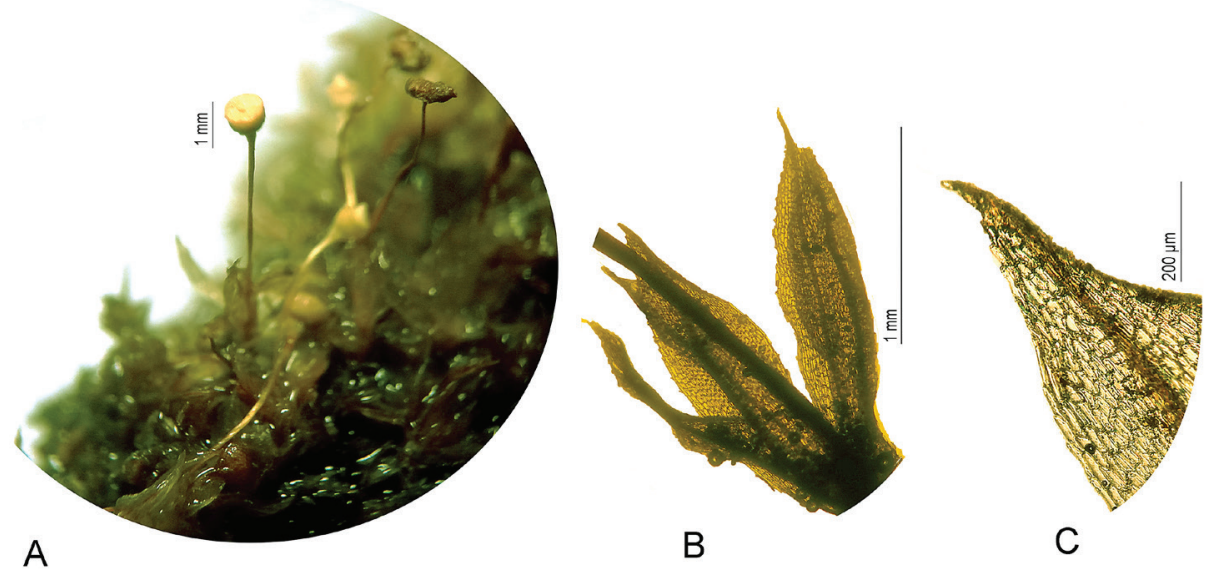

Fig. 1. Habitus of Physcomitrium eurystomum: sporophytes with urn-shape capsules (A), leaves shape (B) and leaf detail (C). 


\section{References}

Anđić, B., Berg, C., Stešević, D., 2018: New and interesting bryophytes of Albania and Montenegro. Herzogia 31, 436-443.

BAFU, 2011: Liste der National Prioritären Arten. Arten mit nationaler Priorität für die Erhaltung und Förderung, Stand 2010. Umwelt-Vollzug 1103. Bundesamt für Umwelt, Bern.

Deil, U., 2005: A review on habitats, plant traits and vegetation of ephemeral wetlands - a global perspective. Phytocoenologia $35,533-706$.

Dierßen, K., 2001: Distribution, ecological amplitude and phytosociological characterization of European bryophytes. Bryophytorum Bibliotheca 56. J. Cramer, Berlin, Stuttgart.

ECCB, 2016: European working list of mosses, Version 6.0 (26/02/2016). Retrieved January, 2019 from https://eccbbryo. nhmus.hu/node/23

Hodgetts, N., 2011: A revised Red List of bryophytes in Britain. Field Bryology 103, 40-49.

Hodgetts, N.G., 2015: Checklist and country status of European bryophytes - towards a new Red List for Europe. Irish Wildlife Manuals, No. 84. National Parks and Wildlife Service, Department of Arts, Heritage and the Gaeltacht, Ireland.

Hodgetts, N., Cálix, M., Englefield, E., Fettes, N., García Criado, M., Patin, L., Nieto, A., Bergamini, A., Bisang, I., Baisheva, E., Campisi, P., Cogoni, A., Hallingbäck, T.,Konstantinova, N., Lockhart, N., Sabovljevic, M., Schnyder, N., Schröck, C., Sérgio, C., Sim Sim, M., Vrba, J., Ferreira, C.C., Afonina, O., Blockeel, T., Blom, H., Caspari, S., Gabriel, R., Garcia, C., Garilleti, R., González Mancebo, J., Goldberg, I., Hedenäs, L., Holyoak, D., Hugonnot, V., Huttunen, S., Ignatov, M., Ignatova, E., Infante, M., Juutinen, R., Kiebacher, T., Köckinger, H., Kučera, J., Lönnell, N., Lüth, M., Martins, A., Maslovsky, O., Papp, B., Porley, R., Rothero, G., Söderström, L., Ştefănuţ, S., Syrjänen, K., Untereiner, A., Váňa, J. I, Vanderpoorten, A., Vellak, K., Aleffi, M., Bates, J., Bell, N., Brugués, M., Cronberg, N., Denyer, J., Duckett, J., During, H.J., Enroth, J., Fedosov, V., Flatberg, K.-I., Ganeva, A., Gorski, P., Gunnarsson, U., Hassel, K., Hespanhol, H., Hill, M., Hodd, R., Hylander, K., Ingerpuu, N., Laaka-Lindberg, S., Lara, F., Mazimpaka, V., Mežaka, A., Müller, F., Orgaz, J.D., Patiño, J., Pilkington, S., Puche, F., Ros, R.M., Rumsey, F., Segarra-Moragues, J.G., Seneca, A., Stebel, A., Virtanen, R., Weibull, H., Wilbraham, J., Żarnowiec, J., 2019: A miniature world in decline: European Red List of Mosses, Liverworts and Hornworts. IUCN, Brussels, Belgium.

Ingerpuu, N., Vellak, K., Ehrlich, L., 2018: Revised Red Data List of Estonian bryophytes. Folia Cryptogamica Estonica 55, 97-104.
Kučera, J., Váňa, J., 2003: Check- and Red List of bryophytes of the Czech Republic. Preslia 75, 193-222.

Markišić, H., Martinović, Ž., 1998: About the find of Serbian ramonda (Ramonda serbica) in the gorge of Bukovička river. Rožajski zbornik 8, 203-225.

Martinčić, A., 2016: Updated Red List of bryophytes of Slovenia. Hacquetia 15, 107-126.

Maslovsky, O., 2005: Rare and threatened bryophytes and a proposal for an Eastern European Red Book. Boletín de la Sociedad Española de Briología 26-27, 47-54.

Papp, B., Erzberger, P., Ódor, P., Hock, Z.S., Szövényi, P., Szurdoki, E., Tóth, Z., 2010: Updated checklist and red list of Hungarian bryophytes. Studia Botanica Hungarica 41, 31-59.

Papp, B., Szurdoki, E., Pantović, J., Sabovljević, M., 2013: Physcomitrium eurystomum and Pohlia proligera, new mosses in the bryophyte flora of Serbia. Archives of Biological Sciences, Belgrade 65, 703-706.

Porley, R., 2013: "Physcomitrium eurystomum: Norfolk Bladder." England's Rare Mosses and Liverworts: Their History, Ecology, and Conservation. Princeton University Press, Princeton, New Jersey; Woodstock, Oxfordshire.

Ros, R.M., Mazimpaka, V., Abou-Salama, U., Aleffi, M., Blockeel, T.L., Brugués, M., Cros, R.M., Dia, M.G., Dirkse, G.M., Draper, I., El-Saadawi, W., Erdağ, A., Ganeva, A., Gabriel, R., González-Mancebo, J.M., Granger, C., Herrnstadt, I., Hugonnot, V., Khalil, K., Kürschner, H., Losada-Lima, A., Luís, L., Mifsud, S., Privitera, M., Puglisi M.,, Sabovljević, M., Sérgio, C., Shabbara, H.M., Sim-Sim, M., Sotiaux, A., Tacchi, R., Vanderpoorten, A., Werner,O., 2013: Mosses of the Mediterranean, an annotated checklist. Cryptogamie, Bryologie 34, 99-283.

Sabovljević, M., Ganeva, A., Tsakiri, E., Ştefănuţ, S., 2001: Bryology and bryophyte protection in south-eastern Europe. Biological Conservation 101, 73-84.

Sabovljević M., Cvetić, T., Stevanović, V., 2004: Bryophyte Red List of Serbia and Montenegro. Biodiversity and Conservation 13, 1781-1790.

Sabovljević, M., Natcheva, R., Dihoru, G., Tsakiri, E., Dragićević, S., Erdag, A., Papp, B., 2008: Check-list of the mosses of Southeast Europe. Phytologia Balcanica 14, 159-196.

Smith, A.J.E., 2004: The moss flora of Britain and Ireland. Cambridge University Press, Cambridge.

Šoltés, R., Kubinská, A., Janovicová, K., 2002: Extinction risk to the Bryophytes in Slovakia, reasons and evaluation. Portugaliae Acta Biologica 20, 57-63. 